\title{
PERAN GURU DALAM MENINGKATKAN MORAL ANAK USIA DINI DI TK IT QURROTA A'YUN PONOROGO
}

\author{
Sofi Hurmaini \\ Institut Agama Islam Negri Ponorogo \\ Email: shofiananda@gmail.com
}

\begin{abstract}
This study aims to understand: 1) What is the role of the teacher as a guide in improving the morale of young children in kindergarten IT Qurrota A'yun Ponorogo; and 2) What is the role of the teacher as an educator in improving the morale of young children in kindergarten IT Qurrota A 'Yun Ponorogo. The research used is qualitative research. This type of research is a case study. Data collection techniques in this study used interviews, and documentation. The data analysis techniques taken by the concept proposed by Miles and Huberman are data reduction, data presentation, and discussed conclusions. The results showed that: 1). In accordance with the preconventional morality of children who do not comply with the rules, they are subject to punishment, such as children who argue without reason, the way the teacher reminds them is by singing; 2). Children are born in good condition, so that learning is requested to be processed by being carried out, carried out, and evaluated and then poured into RPPH.
\end{abstract}

Keywords: teacher's role, early childhood morale

\begin{abstract}
Abstrak: Penelitian ini bertujuan untuk mengetahui : 1) Bagaimana peran guru sebagai pembimbing dalam meningkatkan moral anak usia dini di TK IT Qurrota A'yun Ponorogo;dan 2) Bagaimana peran guru sebagai pendidik dalam meningkatkan moral anak usia dini di TK IT Qurrota A'yun Ponorogo. Penelitian yang digunakan adalah penelitian kualitatif. Jenis penelitian yang digunakan yaitu studi kasus. Teknik pengumpulan data dalam penelitian ini menggunakan wawancara, dan dokumentasi. Adapun teknik analisis data mengikuti konsep yang dikemukakan oleh Miles dan Huberman yaitu reduksi data, penyajian data, dan penarikan kesimpulan. Hasil penelitian menunjukkan bahwa: 1). Sesuai dengan moralitas prakonvensional anak yang tidak patuh sesuai dengan aturan maka dikenai hukuman, semisal anak yang memukul temannya tanpa sebab maka cara guru mengingatkannya adalah dengan sebuah nyanyian; 2). Anak terlahir sudah dalam keadaan baik, sehingga dalam menerapkan pembelajaran disekolah dengan direncanakan, dilaksanakan, dan dievaluasi kemudian dituangkann dalam RPPH.
\end{abstract}

Kata kunci: peran guru, moral anak usia dini

\section{PENDAHULUAN}

Kosa kata "guru" berasal dari kosa kata yang sama dalam bahasa India yang artinya "orang yang mengajarkan tentang kelepasan dan kesengsaraan". Dalam tradisi agama Hindu, guru dikenal sebagai maha resi guru. Yakni para pengajar yang bertugas untuk mendidik para calon biksu. Dalam bahasa Arab, kosa kata guru dikenal dengan al- mu'allim atau al ustadhyang bertugas memberikan ilmu dalam majlis taklim (tempat memperoleh ilmu). Dengan demikian sama dengan pengertian guru dalam 
agama Hindu, al-mu'allim atau al- ustadhah. Dalam hal ini juga memiliki pengertian orang yang mempunyai tugas untuk membangun ritual aspek spiritual manusia ${ }^{1}$ Pendidikan sebagai agen of change memiliki peranan yang sangat strategis dalam menyiapkan generasi masa depan yang tangguh, kokoh dan kredibel. Peran tersebut menjadi lumrah mengingat pendidikan merupakan investasi tak terhingga bagi masa depan generasi anak bangsa. Dalam tombak pendidikan memiliki peran yang sangat strategis untuk menunjukkan mutu dan kualitas pendidikan di negeri ini.

Guru ialah seorang yang diberi tugas, wewenang dan tanggung jawab oleh pejabat yang berwenang untuk melaksanakan pendidikan di sekolah, termasuk hak yang melekat dalam jabatan. Pendidik merupakan tenaga profesional yang bertugas merencanakan dan melaksanakan proses pembelajaran, menilai hasil pembelajaran, melakukan pembimbingan, dan pelatihan, serta melakukan penelitian dan pengabdian kepada masyarakat. Guru sebagai figur sentral dalam pendidikan,haruslah mempunyai tanggung jawab dan keagamaan untuk mendidik anak didiknya menjadi orang yang berilmu dan berakhlak. ${ }^{2}$ Dengan kepercayaan yang diberikan masyarakat, maka dipundak guru diberikan tugas dan tanggung jawab yang berat. Mengemban tugas memang berat. Tapi lebih berat lagi mengemban tanggung jawab. Sebab tanggung jawab guru tidak hanya sebatas konteks ini, guru sebagai ujung dinding sekolah, tapi juga di luar sekolah. Dengan demikian dapat disimpulkan bahwa guru adalah yang berwenang dan bertanggung jawab untuk membimbing anak didik, baik secara individu maupun klasikal, di sekolah maupun luar sekolah. ${ }^{3}$

Guru berperan bukan hanya sebagai pelaku perubahan yang menggerakkan roda transformasi sosial, ekonomi, dalam masyarakat.

\footnotetext{
${ }^{1} 1 \mathrm{lbid} ., 9$.

2 Suparlan, Guru sebagai profesi, (Yogyakarta: Hikayat, 2006), h.7

3 Syaiful Bahri Djaramah, Guru dan Anak Didik dalam Interaksi Edukatif (Jakarta; PT Rineka Cipta, 2010), 31
} 
Lebih dari itu guru bisa memiliki peranan utama sebagai pendidik karakter. Guru bukan saja mengubah hidup anak, tetapi juga memperkaya dan memperkokoh kepribadian siswa menjadi insan berkeutamaan karena memiliki nilai-nilai yang ingin diperjuangkan dan diwujudkan dalam masyarakat. Guru bukan hanya mengubah anak didik menjadi anak pandai, melainkan membekali mereka dengan keutamaan dan nilai-nilai yang mempersiapkan mereka menjadi insan yang bertanggungjawab terhadap diri sendiri, orang lain, masyarakat dan yang terpenting adalah kepada Tuhan Yang Maha Esa.

Secara bahasa pendidik atau guru adalah educator walaupun dalam penggunaan sehari-hari lebih dikenal dengan istilah teacher sebagai orangyang melakukan transfer of knowledge sekalian transfer of value. Sebagaimana telah dijelaskan oleh pakar psikologi terkenal Howard Gadner. Dengan demikian, guru dapat diartikan sebagai orang yang tugasnya terkait dengan upaya mencerdaskan kehidupan bangsa dalam semua aspeknya, baik spiritual, emosional, intelektual, fisikal maupun aspek lainnya. Dalam bahasa teknis edukatif guru terkait dengan kegiatan untuk mengembangkan peserta didik dalam ranah kognitif, afektif dan psikomotor.

Guru sangatlah berperan dalam membantu perkembangan peserta didik untuk mewujudkan tujuan hidupnya secara optimal. Keyakinan ini muncul karena manusia adalah makhluk lemah, yang dalam perkembangannya, senantiasa membutuhkan orang lain, sejak lahir, bahkan pada saat meninggal. Semua itu mewujudkan bahwa setiap orang membutuhkan orang lain dalam perkembangannya, demikian halnya seperti peserta didik, ketika orangtua mendaftarkan anaknya ke sekolah pada saat itu juga ia menaruh harapan terhadap guru, agar anaknya dapat berkembang secara optimal. Sebagai pembimbing, guru juga perlu 
memiliki kemampuan untuk dapatmembimbing siswa. ${ }^{4}$

Guru harus merumuskan dengan jelas, menetapkan waktu perjalanan, menetapkan perjalanan yang ditempuh, menggunakan petunjuk perjalanan, serta menilai kelancarannya sesuai dengan kebutuhan dan kemampuan peserta didik. Tetapi guru memberikan pengaruh pertama dalam aspek perjalanan anak. Tidak cukup kata atau ungkapan yang memadai untuk menjelaskan tentang tingginya posisi guru. Dalam situasi formal, selain sebagai pengajar dan pendidik dilingkungan sekolah.

Moralitas dalam arti sesungguhnya yaitu; (a) prilaku yang sesuai dengan standar sosial dan dilaksanakan secara suka rela, (b) tingkah laku yang benar-benar berasal dari diri seseorang yang disertai dengan perasaan tanggung jawab pribadi, (c) lebih mementingkan bagaimana kepentingan atau kesejahteraan kelompok daripada keinginan dan kepentingan pribadi, (d) jarang ditemukan pada masa kanak- kanak, tetapi harus sudah mulai muncul pada masa kanak-kanak, tetapi harus sudah mulai muncul pada masa remaja. ${ }^{5}$ Perkembangan moral anak sangat dipengaruhi oleh lingkungan sekitar. Pendidikan moral untuk anak usia dini tidak dapat dianggap remeh karena moral merupakan suatu hal yang sangat penting dan sangat berpengaruh dalam kehidupan sosial masyarakat seseorang. Jika eksistensi moral diabaikan maka kekacauan dan permasalahan akan bermunculan sehingga mengakibatkan keterpurukan di segala sisi kehidupan.

Seiring dengan perkembangan sosial, anak-anak usia prasekolah juga mengalami perkembangan moral. Adapun yang dimaksud dengan perkembangan moral adalah perkembangan yang berkaitan dengan aturan dan konvensi mengenai apa yang seharusnya dilakukan oleh

\footnotetext{
${ }^{4}$ Suparlan, Guru Sebagai Profesi, 33.

5 Bambang Sujiono, Mencerdaskan Prilaku Anak Usia Dini, (Jakarta: Elex Media Komputindo, 2007), 4
} 
manusia dalam interaksinya dengan orang lain. Anak-anak ketika dilahirkan tidak memiliki moral (imoral). Tetapi dalam dirinya terdapat potensi moral yang siap berinteraksi dengan orang lain (dengan orang tua, saudara dan teman sebaya), anak belajar memahami tentang perilaku mana yang baik, yang buruk, yang boleh dikerjakan dan tingkah laku mana yang buruk, yang tidak boleh dikerjakan. Nilai-nilai moral yang dijunjung tinggi oleh sekelompok sosial berarti terdapat aturan-aturan di dalamnya. Sejalan dengan perkembangan sosial, perkembangan keagamaan mulai disadari bahwa terdapat aturan-aturan prilaku yang boleh, harus, atau terlarang untuk melakukannya. Aturan-aturan prilaku yang boleh atau tidak boleh tersebut adalah moral.

Tahapan perkembangan moral menurut Piaget Terdiri dari dua tahapan, yaitu tahap realism moral, dan tahap moralitas otonomi.

a. Tahap realisme moral

Tahap realisme moral yaitu moralitas yang dilakukan oleh anak akibat adanya pembatasan- pembatasan yang dilakukan oleh orang dewasa. Contoh: anak- anak harus masuk sekolah pukul 07.00, jika lebih dari itu berarti melanggar peraturan. Anak yang melanggar peraturan akan dikenai sanksi atas perbuatan yang dilakukannya. Pada tahap ini prilaku anak ditentukan oleh; (1) kataatan otomatis terhadap peraturan tanpa pemaksaan, penilaian, dan pemahaman, (2) anak mengikuti begitu saja apa yang diinginkan dan diharapkan orang dewasa, mereka mengabaikan tujuan atas tindakannya. la harus melihat contoh suatu tindakan dianggap salah karena mengakibatkan ia dihukum.

b. Tahap moralitasotonomi

Moralitas oleh adanya kerjasama atau hubungan timbal balik dengan lingkungan dimana anak berada. Contoh; anak berjalan menunduk dihadapan orang yang lebih tua, prilaku yang 
mendasarinya adalah agar ia terlihat sopan. Pada tahap ini, prilaku anak ditentukan oleh: (1) anak menilai prilaku atas tujuan yang mendasarinya, (2) di mulai pada usia 7-12 tahun, (3) konsep anak tentang keadilan mulai berubah yang dilihat dan ditiru dari orang dewasa, (4) muncul situasi baru dimana "berbohong" dibenarkan untuk satu situasi tertentu yang ia pelajari orang dewasa.

Tahap perkembangan moral menurut Kholberg Terdapat tiga tingkatan yaitu;

a. Moralitas prakonvensional

Tahap satu, anak berorientasi pada kepatuhan dan hukuman. Moralitas dari suatu tindakan dinilai atas dasar akibat fisiknya. Contoh" bersalah kemudian dicubit ".Kakak membuat adik menangis, maka ibu memukul/mencubit tangan kakak. Tahap kedua, anak menyesuaikan terhadap harapan sosial untuk memperoleh penghargaan. Contoh; "berbuat benar, kemudian dipuji". Anak yang mengerjakan tugas dengan baik akan diberi ungkapan "pintar sekali".

b. Moralitas konvensional

Tahap satu, seseorang menyesuaikan dengan peraturan untuk mendapatkan persetujuan orang lain dan untuk mempertahan hubungan baik dengan mereka. Contohnya adalah mengembalikan krayon ke tempat semula sesudah digunakan (nilai moral = tanggung jawab). Tahap kedua, seseorang yakin bahwabila kelompok sosial menerima peraturan yang sesuai bagi seluruh anggota kelompok, maka mereka harus berbuat sesuai dengan peraturan itu agar terhindar dari keamanan dan ketidak setujuan sosial. Contohnya adalah bersama-sama membersihkan kelas semua anggota kelompok wajib membawa alat kebersihan (nilai moral = gotong royong). 
c. Moralitas pascakonvensional

Tahap satu, seseorang perlunya keluwesan dan adanya modifikasi dan perluasan standar moral apabila itu dapat menguntungkan kelompok secara keseluruhan. Contohnya pada ajaran baru sekolah memperkenankan orang tua menunggu anaknya selama lebih kurang satu minggu, setelah itu anak setelah itu anak harus berani ditinggal. Tahap kedua, seseorang menyesuaikan dengan standar sosial dan cita- cita internal terutama untuk menghindari rasa tidak puas dengan diri sendiri dan bukan untuk menghindari kecaman sosial (orang yang tetap mempertahankan moralitas tanpa rasa takut dari kecaman orang lain). Contohnya adalah anak secara sadar merapikan kamar tidurnya setelah ia bangun tidur dengan harapan agar kamarnya terlihat selalu dalam keadaan rapi ${ }^{6}$.

Lawrence Walker dalam John W. Santrock telah meneliti karakter moral dengan cara melihat konsepsi seseorang terhadap kesempurnaan moral. Diantara banyak kebajikan moral, orang- orang menekankan " kejujuran, terus terang, dapat dipercaya,dan juga perhatian,rasa kasihan, memikirkan orang lain juga kepedulian trait salient yang lain yang juga ada disekitar kebajikan ini antara lain dapat diandalkan kesetiaan, dan berhati-hati. ${ }^{7}$ Berbagai jawaban timbul ketika ditanyakan prinsip moral apa yang diinginkan orang tua, namun secara umum jawaban- jawaban tersebut dapat digolongkan pada perkembangan prinsip prilaku prososial, tumbuhnya kontrol diri dalam menghindari menyakiti orang lain, disertai internalisasi atau komitmen pribadi untuk pemenuhan aturan yang ada. Altruisme perkembangan prilaku prososial,kontrol prilaku

${ }^{6}$ Sujiono, Mencerdaskan Prilaku Anak Usia Dini, (Jakarta:Elex Media,2004), 6-8.

7 John W. Santrock, Perkembangan Anak Jilid II, (Jakarta: Gelora Aksara Pratama 2007) 131. 
agresivitas,menerapkan prinsip keadilan sosial. ${ }^{8}$

Hasil observasi yang dilakukan peneliti di TK IT Qurrota A'yun Ponorogo bahwa rata-rata moral anak sudah baik, akan tetapi ada beberapa anak yang masih butuh perhatian khusus. Hal tersebut ditunjukkan dengan adanya anak yang memukul temannya tanpa sebab sehingga cara guru mengingatkannya dengan sebuah nyanyian. Lagunya yaitu "tanganmu yang mungil jagalah-jagalah jangan sampai memukul yang salah yang salah karena kau diawasi oleh Allah Ta'ala tangan mu yang mungi jagalah-jagalah" Masalah lain yang timbul adalah dengan latar belakang lingkungan yang mempengaruhi anak. Anak ketika disekolah dan di rumah sudah diajarkan moral yang baik oleh guru dan orang tua akan tetapi ketika di lingkungannya kurang baik maka anak akan terpengaruh juga. Setelah melihat uraian di atas, maka tampak bahwa peran guru sebagai pembimbing dan pendidik sangat berperan aktif dalam membentuk moral anak agar menjadi yang lebih baik. Begitu juga dengan orang tua yang selalu memberikan contoh- contoh yang baik ketika di rumah agar anak selalu terbentuk menjadi anak yang bermoral.

\section{METODE PENELITIAN}

Dalam penelitian ini digunakan metode penelitian dengan menggunakan pendekatan kualitatif, yaitu prosedur penelitian yang menghasilkan data deskriptif kualitatif berupa kata-kata tertulis atau lisan dari orang- orang dan perilaku yang diamati ${ }^{9}$

Dalam penelitian ini, jenis penelitian yang digunakan adalah studi kasus yaitu kajian dengan memberi batasan yang tegas terhadap suatu objek dan subjek penelitian tertentu, melalui pemusatan perhatian pada

\footnotetext{
${ }^{8}$ Aliah B. Purwakania Hasan, Psikologi Perkembangan Islam (Jakarta; PT Rajagrafindon Persada, 2006), 263- 269

${ }^{9}$ Andi Prastowo, Metode Penelitian Kualitatif dalam Prespektif Rancangan

Penelitian,(Jogjakarta: Ar-Ruzz Media, 2014), 22
} 
suatu kasus secara intensif dan rinci. ${ }^{10}$ Adapun subjek dari penelitian ini adalah kepala sekolah, dewan guru, seluruh siswa diTK IT Qurrota A'yun, beserta seluruh kegiatan yang berkaitan dengan moral anak usia dini

\section{HASIL DAN PEMBAHASAN}

Pernyataan dari lbu Nur Syamsiyah selaku kepala sekolah di TK IT Qurrota A'yun Ponorogo bahwa upaya gurudalam meningkatkan moral anak usia dini adalah dengan pendekatan personal. Supaya moral anak menjadi baik, kita sebagai orang tua harus menanamkan nilai agama, budi pekerti dan lebih memberikan bimbingan pada anak jika anak memiliki waktu luang. Di sisi lain suasana rumah tangga dari ayah dan ibu juga harus baik, jangan sampai ada masalah dalam rumah tangga supaya tidak mempengaruhi pada anak. Karena anak usia dini membutuhkan bimbingan yang baik untuk dapat menerapkan nilai moral serta ilmu agama untuk kebaikan anak.

Selain itu, seorang peneliti menemukan bahwa di TK IT Qurrota A'yun Ponorogo ada beberapa anak yang memukul temannya tanpa sebab. Sehingga seorang guru melerai anak tersebut dengan sebuah nyanyian yaitu " tangan mu yang mungil jagalah-jagalah jangan sampai memukul yang salah yang salah karena kau diawasi oleh Allah Ta'ala tangan mu yang mungil jagalah-jagalah". Jika anak tersebut menendang temannya maka guru melerai nya dengan nyanyian yang sama yaitu " kaki mu yang mungil jagalah-jagalah jangan sampai memukul yang salah yang salah karena kau diawasi oleh Allah Ta'ala kaki mu yang mungil jagalahjagalah"

Dalam meningkatkan moral anak usia dini semestinyamemerlukan beberapa langkah yaitu yang utama dengan pendekatan personal baik di sekolah maupun di rumah. Semua kegiatan pembelajaran dilakukan

\footnotetext{
${ }^{10}$ Rully Indrawan, Poppy Yaniawati, Metodologi Penelitian, (Bandung: PT Refika
} Aditama, 2014), 72. 
dengan cara direncanakan, dilaksanakan, kemudian dievaluasi dan dituangkan dalam RPPH, agar kegiatan belajar berjalan dengan lancar sesuai yang diharapkan.

Upaya guru sebagai pendidik dalam meningkatkan moral anak usia dini adalah dalam mendidik anak antara guru dan orang tuaharus bersinergi bersama. Ketika di sekolah guru sudah memberikan contohcontoh yang baik, seperti pembiasaan-pembiasaan berdo'a sebelum dan sesudah makan, sholat Dhuha dan Dzuhur berjama'ah. Di rumah orang tua juga harus memberikan contoh yang baik kepada anak. Meskipun anak masih kecil. Karena anak itu meniru tingkah laku orang tua ketika di rumah dan menerapkan ketika sampai disekolah. Mendidik anak itu tidak akan berhasil kalau hanya ketika di sekolah saja. Tetapi ada orang tua yang selalu mendukung dan memotivasi anak.

Anak terlahir fithroh dalam keadaan, sehingga anak sudah mempunyai kebaikan- kebaikan tersendiri, sudah mempunyai bekal dari rumah. Anak sudah bisa dikatakan mempunyai moral yang baik, langkahlangkah dalam meningkatkan moral anak disekolah yaitu dengan cara direncanakan, dilaksanakan, dan dievaluasi. Caranya yaitu dengan pembiasaan-pembiasaan. Contohnya seperti mengucapkan salam, menyayangi teman, dll. Yang awalnya ketika dirumah buang air kecilnya berdiri kemudian ketika disekolah diterapkan dengan cara duduk. Semua itu sudah dituangkan dalam RPPH.

Jadi dalam meningkatkan moral anak di TK IT Qurrota A'yun Ponorogo adalah bahwa anak sudah terlahir baik. sehingga dalam menerapkan kegiatan pembelajaran adalah dengan di rencanakan, dilaksanakan, dan dievaluasi kemudian dituangkan dalam RPPH.

\section{PEMBAHASAN}

Guru berperan bukan hanya sebagai pelaku perubahan yang menggerakkan roda transformasi sosial, ekonomi dalam masyarakat. 
Lebih dari itu guru bisa memiliki peranan utama sebagai pendidik karakter. Guru bukan saja mengubah hidup anak, tetapi juga memperkaya dan memperkokoh kepribadian siswa menjadi insan berkeutamaan karena memiliki nilai-nilai yang ingin diperjuangkan dan dan diwujudkan dalam masyarakat. Guru bukan hanya mengubah anak didik menjadi anak pandai , melainkan membekali mereka menjadi insan yan bertanggung jawab terhadap diri sendiri, orang lain, masyarakat dan yang terpenting adalah kepada Tuhan Yang Maha Esa.

Dengan demikian, bahwa guru sangat berperan sekali dalam kegiatan belajar mengajar. Begitu juga dengan guru yang ada di TK IT Qurrota A'yun Ponorogo sangat berperan aktif, sehingga dalam kegiatan belajar mengajar di kelas berjalan dengan lancer. Mayoritas guru di TK IT Qurrota A'yun Ponorogo memiliki latar pendidikan keilmuan di bidang anak usia dini. Sebagai pembimbing, guru diibaratkan sebagai pembimbing perjalanan, yang berdasarkan pengetahuan dan pengalamannya bertanggung jawab atas kelancaran perjalanan itu. Dalam hal ini, istilah perjalanan tidak hanya menyangkut fisik tetapi juga perjalanan mental, emosional, kreatifitas, moral, dan spiritual yang lebih dalam dan kompleks. Sebagai pembimbing, guru harus merumuskan tujuan secara jelas, menerapkan waktu perjalanan, serta menilai kelancarannya sesuai dengan kebutuhan dan kemampuan peserta didik. ${ }^{11}$

Peran guru sebagai pembimbing di TK IT Qurrota A'yun Ponorogo bahwa sangat Mempengfaruhi dalam meningkatkan mporal anak. Yang dilakukan guru sebagai pembimbing yaitu dengan menerapkapkan beberapa langkah yaitu, semua direncanakan, dilaksanakan, kemudian di evaluasi apa yan g telah dilaksanakan tadi. Kemudian dituangkan dalam bentuk RPPH. Contohnya kegiatan cuci tangan sebelum makan. Diterapkan dalam RPPH dalam sentra alam yaitu anak ke kamar mandi cuci tangan memakai sabun dan setelah itu makan.

11 Isjoni, Guru Sebagai Motivator Peerubahan, (Yogyakarta: Puataka Pelajar, 2008), 26-27 
Pengertian moralitas adalah sifat moral atau keseluruhan asas dan nilai yang berkenaan dengan baik dan buru ${ }^{12}$. Senada dengan pengertian tersebut, W Poespoprodjo mendefinisikan moralitas sebagai "kualitas dalam perbuatan manusia yang menunjukkan bahwa perbuatan itu benar atau salah, baik atau buruk". Moralitas mencakup baik buruknya perbuatan manusia. TK IT Qurrota A'yun Ponorogo memiliki siswa yang moralnya baik. Hanya saja perlu perhatian yang lebih. Nak yang moralnya kurang bukan berarti dikatakan tidak bermoral, karena pada dasarnya moral anak tersebut belum berkonseop. Anak sudah mempunyai kebaikan-kebaikan tersendiri.

Maka dari itu, peranan guru sangat diperlukan dalam kegiatan belajar mengajar anak. Guru di TK IT Qurrota A'yun Ponorogo memberikan pengenalan yang mengena kepada anak yaitu dengan kebiasaan-pembiasaan-pembiasaan yang dilakukan oleh guru. Contohnya seperti ketika sampai disekolah anak berjabat tangan guru ketika sampaidi sekolah maupun ketika pulang sekolah. Guru diibaratkan sebagai pembimbing perjalanan, yang berdasarkan pengetahuan dan pengalamannya bertanggung jawab atas kelancaran perjalanan itu. Dalam hal ini, istilah perjalanan tidak hanya menyangku fisik, tetapi juga perjalanan mental, emosional, kreatifitas, moral, dan spiritual yang lebih dalam kompleks. Sebagai pembimbing, guru harus merumuskan tujuan secara jelas, menetapkan waktu perjalanan, , serta menilai kelancarannya sesuai dengan kebutuhan dan kemampuan peserta didik.

Berdasarkan kenyataan bahwa di TK IT Qurrota A'yun Ponorogo peran guru sebagai pembimbing dalam meningkatkan moral anak sesuai dengan moralitas prakonvensiaonal yaitu apabilaada salah satu anak yang tidak patuh atau sesuai dengan aturan sekolah maka anaknya dikenai hukuman semisal ada anak yang memukul temannya tanpa sebab maka guru memberi hukumannya adalah dengan mengingatkan anak

${ }^{12}$ Asmara As, Pengantar Studi Akhlak, (Rajawali Press, Jakarta 1992), 8. 
tersebut dengan sebuah nyayian yaitu "tangan mu yang mungil jagalahjagalah jamgan sampai memukul yang salah yang salah karena kau diawasi oleh Allah Ta'ala tangan mu yang mungil jagalah-jagala Berdasarkan paparan diatas dapat dikatakan bahwa peran guru sebagai pembimbing dalam meningkatkan moral anak usia dini di TK IT Qurrota A'yun Ponorogo adalah dengan sebagai pendidik, dalam Undang-Undang Nomor 20 Tahun 2003, Bab XI Pasal 39 Ayat 2 dikatakan bahwa guru sebagai pendidik adalah tenaga professional yang bertugas merencanakan dan melaksanakan proses pembelajaran, menilai hasil pembelajaran, melakukan pembimbingan dan pelatihan serta melakukan penelitian dan pengabdian kepada masyarakat.

Guru adalah pendidik, yang menjadi tokoh, panutan dan identifikasi bagi para peserta didik, dan lingkungannya. Oleh karena itu, guru harus memiliki standar kualitas tertentu, yang mencakup tanggung jawabwibawa, mandiri dan disiplin. ${ }^{1313}$ Begitu juga pendidikan yang ada di TK IT Qurrota A'yun Ponorogo, bahwa dalam pendidikannya sangat disiplin sekali ketika di sekolah, berangkat pagi dan menyambut peserta didik dan bersalaman ketika sampai di sekolah. Itu adalah kegiatan setiap pagi yang dilakukan peserta didik secara bergantian.

Yang dilakukan guru sebagai pendidik di TK IT Qurrota A'yun Ponorogo dalam meningkatkan moral anak usia dini yaitu dengan beberapa langkah. Yaitu diawali dengan pembiasaan sholat dhuha berjamaah, berdo'a sebelum dan sesudah makan. Factor-faktor yang mempengaruhi perkembnagan moral anak banyak dipengaruhi oleh lingkungannya. Anak memperoleh nilai-nilai moral dari lingkungannya, terutama dari orang tuanya. Dia belajar untuk mengetahui nilai-nilai dan prilaku sesuai dengan nilai-nolai tersebut. Dalam perkembngan moral anak, peranan orang tua sangatlah penting, terutama pada anak saat masih kecil. Beberapa sijkap orang tua yang perlu diperhatiakn

\footnotetext{
${ }^{13}$ Mulyasa, Sertifikasi Guru,(Bandung, Pustaka Pelajar, 2008), 19.
} 
sehubungan dengan perkembangan moral anak, diantaranya;

a. Konsisten dalam mendidik anak

b. Sikap orang tua dalam keluarga

c. Penghayatandan pengamatan agama yang dianut

d. Sikap konsisten orang tua dalam menerpakan norma

Di TK IT Qurrota A'yun Ponorogo guru sebagai pendidik dalam mendidik anak usia dini itu pendidik selalu menekankan kepada wali murud untuk bersinergi bersama. Kalau hanya mengandalkan guru saja, dlam istilah menitipkan anak ke sekolah itu tidak akan berhasil. Guru juga harus memberi contoh yang baik ketika dirumah. Di lingkungan juga akan mempengaruhi perkembangan moral anak usia dini. Agar seseorang guru dapat menjalankan fungsinya sebagai pendidik, maka ia harus memiliki sifat-sifat berikut ini;

Setiap pendidik ;harus memiliki sifat rabbani, yaitu memiliki ketaatan kepada Tuhan Yang Maha Esa. Seseorang guru hendaknya menyempurnakan sifat rabbaninya dengan keikhlasan Seseorang pendidik hendaknya mengajarkan keilmuannya dengan sabar Seseorang pendidik harus memiliki kejujuran dengan menerapkan apa yang dia ajarkan dalam kehidupan pribadinya. Seseorang guru harus senantiasa meningkatkan wawasan dan pengetahuannya. Seorang pendidik harus cerdik dan terampil dalam menciptakan metode pengajaran yang variatif serta sesuai dengan situasi dan materi pelajaran.

Begitu juga yang diterapkan oleh pendidik di TK IT Qurrota A'yun Ponorogo bahwa dalam setiap pembelajaran guru harus kreatif dan membuat inovasi dalam membuat permainana., dalam permainan tersebut mengandung nilai moral yang sangat mengena kepada anak. Mengajarkan sifat sabar dalam bermain, mau berbagi sesame temannya, dan anak mau bergantian mainan kepada temannya

Setiap anak memiliki perkembangan moral yang berbeda-beda, ada 
yang memiliki perkembangan moral kurang baik da nada pula yang memiliki perkembangan baik. Ada beberapa pendapat ahlui mengenai perkembangan moral . hakikat dari perkembangan moral itu sendiri menurut Ahmad dan Sholeh adalah suatu proses yang menuju ke depan tidak dapat diulangi kembali. Perkembangan anak usia dini dapat dilihat dari beberapa aspek perkembangan seperti aspek kognitif, aspek bahasa, aspek fisik motoric, yang terdiri dari motoric halus dan kasar, aspek nilai agama dan moral, aspek sosio emosional dan seni.

Perkembangan moral anak sang dipengaruhi oleh lingkungan sekitar. Pendidikan moral anak tidak dapat dianggap remeh karena moral merupakan suatu hal yang sangat berpengaruh dalam kehidupan sosial masyarakat seseorang. Perkembangan moral adalah perkembangan yang berkaitan dengan aturan dan konvensi mengenai apa yang seharusnya dilakukan oleh manusia dalam interaksinya dengan orang lain. Anak-anak ketika dilahirkan tidak memiliki moral . tetapi dalam dirinya terdapat potensi moral yang siap untuk dikembangkan. Karena itu, mengenai pengalamannya, nberinteraksi dengan orang lain, anak belajar memahami tentang prilaku yang baik, yang boleh dikerjakan dan tingkah laku yang buruk, yang tidak boleh dikerjakan. Unsur hubungan timbal balik ini sedemikian penting karena hanya dengan adanya interaksi brbagai aspek dalam diri seseorang (kognitif, afektif, psikomotorik) denga sesamanya atau denag lingkungannya, menjadi semakin dewasa secara fisik, spiritual dan moral.

Jadi peran guru sebagai pendidik dalam meningkatkan moral anak dini di TK IT Qurrota A'yun Ponorogo adalah bahwa anak sudah terlahir baik. sehingga dalam menerapkan kegiatan pembelajaran adalah dengan di rencanakan, dilaksanakan, dan dievaluasi kemudian dituangkan dalam RPPH. 


\section{KESIMPULAN}

Berdasarkan analisis dan pembahasan diatas, dapat disimpulkan bahwa :

1. Peran guru sebagai pembimbing dalam meningkatkan moral anak usia dini di TK IT Qurrota A'yun Ponorogo sesuai dengan moralitas prakonvensiaonal yaitu apabila ada salah satu anak yang tidak patuh atau sesuai dengan aturan sekolah maka anaknya dikenai hukuman semisal ada anak yang memukul temannya tanpa sebab maka guru memberi hukumannya adalah dengan mengingatkan anak tersebut dengan sebuah nyayian yaitu "tangan mu yang mungil jagalah-jagalah jamgan sampai memukul yang salah yang salah karena kau diawasi oleh Allah Ta'ala tangan mu yang mungil jagalah-jagalah".

2. Peran guru sebagai pendidik dalam meningkatkan moral anak usia dini anak di TK IT Qurrota A'yun Ponorogo adalah bahwa anak sudah terlahir baik. sehingga dalam menerapkan kegiatan pembelajaran adalah dengan di rencanakan, dilaksanakan, dan dievaluasi kemudian dituangkan dalam RPPH

\section{DAFTAR PUSTAKA}

Aliah B. Purwakania Hasan, Psikologi Perkembangan Islam, Jakarta; PT Rajagrafindon Persada, 2006

Asmara As, Pengantar Studi Akhlak, Jakarta, Rajawali Press, 1992.

Bambang Sujiono, Mencerdaskan Prilaku Anak Usia Dini, Jakarta: Elex Media Komputindo, 2007.

Isjoni, Guru Sebagai Motivator Peerubahan, Yogyakarta: Puataka Pelajar, 2008.

John W. Santrock, Perkembangan Anak Jilid II, Jakarta: Gelora Aksara Pratama 2007.

Mulyasa, Sertifikasi Guru, Bandung: Pustaka Pelajar, 2008. 
WISDOM: JURNAL PENDIDIKAN ANAK USIA DINI

Volume 01 No. 01, Juni 2020

Sujiono, Mencerdaskan Prilaku Anak Usia Dini, Jakarta: Elex Media, 2004.

Suparlan, Guru Sebagai Profesi, 33.

Suparlan, Guru Sebagai Profesi, Yogyakarta : Hikayat, 2006.

Syaiful Bahri Djarama Guru dan Anak Didik dalam Interaksi Edukatif, Jakarta: PT Rineka Cipta,

Syamsu Yusuf, Psikologi Perkembangan Anak dan Remaja, Bandung: PT Remaja Rosdakarya, 2006. 